\title{
PRINSIP-PRINSIP YOGYAKARTA TAHUN 2007 (STUDI YURIDIS EMPIRIS DI PROVINSI JAWA TIMUR)
}

\author{
Tomy Michael dan Kristoforus Laga Kleden \\ Fakultas Hukum, Universitas 17 Agustus 1945 Surabaya \\ Email:tomy@untag-sby.ac.id, kleden@untag-sby.ac.i
}

\begin{abstract}
ABSTRAK
Hak untuk melakukan perkawinan yang pada akhirnya memiliki keluarga telah termaktub dalam Pasal 28B ayat (1) Undang-Undang Dasar Negara Republik Indonesia Tahun 1945 bahwa "Setiap orang berhak membentuk keluarga dan melanjutkan keturunan melalui perkawinan yang sah". Tetapi dalam tataran praktik, pemenuhan hak perkawinan masyarakat LGBT sangat rentan untuk memperoleh perlakuan diskriminatif dalam memperoleh hak-haknya, termasuk hak perkawinan. Hal tersebut disebabkan rendahnya kepedulian negara terhadap warga negaranya sehingga walaupun secara tersirat terdapat perlindungan terhadap masyarakat LGBT dalam Undang-Undang Republik Indonesia Nomor 39 Tahun 1999 tentang Hak Asasi Manusia (UU No. 39-1999) dan Prinsip-Prinsip Yogyakarta Tahun 2007 (PPY 2007). Hal lainnya akibat adanya perbedaan orientasi seksual dan identitas gender masyarakat LGBT maka masyarakat LGBT membutuhkan perlindungan dalam pemenuhan hak perkawinan. Dengan demikian, Pemerintah Pusat dan Pemerintah Daerah wajib menyelenggarakan pemenuhan hak perkawinan sesuai dengan kewenangannya. Berdasarkan latar belakang tersebut peneliti merumuskan masalah penelitian yaitu bagaimana konsep pengaturan norma hukum tentang pemenuhan hak perkawinan bagi masyarakat LGBT di Provinsi Jawa Timur? Metode yang digunakan adalah yuridis empiris dengan mengumpulkan dan mengolah data primer yang kemudian dilakukan analisis berdasarkan data sekunder. Kesimpulan dari penelitian adalah nawacita menunjukkan keberagaman di indonesia. Dan mengakomodir perubahan yang dimungkinkan terjadi karena nawacita telah mencerminkan beberapa konvensi internasional dan tujuan bangsa. Terkait dengan PPY 2007 maka penghormatan dan penghargaan pada semua perbedaan merupakan bagian dari etika kehidupan yang terus berkembang sesuai dengan perkembangan teknologi. Nawacita merupakan kesatuan yang tidak dapat dipisahkan dengan PPY 2007.
\end{abstract}

\section{PENDAHULUAN}

Di dalam kehidupan orang sebagai subjek hukum selalu memiliki tujuan akhir. Tujuan akhir dapat berupa eksistensi untuk mencapai apa yang diinginkan dalam hidupnya atau untuk menegasikan diri dari subjek hukum lainnya. Pemahaman demikian merupakan hal yang sulit dicerna apabila dikaitkan dengan makna keluarga. Pemberian makna atas keluarga adalah salah satu cara mencapai tujuan akhir karena dalam penelitian ini hal yang dibahas adalah pemenuhan hak perkawinan dimana salah satunya dengan keluarga.

Argumen demikian apabila dikorelasikan dengan Pasal 28B ayat (1) Undang-Undang Dasar Negara Republik Indonesia Tahun 1945 (UUD NRI Tahun 1945) yang termaktub bahwa "Setiap orang berhak membentuk keluarga dan melanjutkan keturunan melalui perkawinan yang sah" dan Pasal 1 Undang-Undang Republik Indonesia Nomor 1 Tahun 1974 tentang Perkawinan (UU No. 1-1974) bahwa "Perkawinan ialah ikatan lahir bathin antara seorang pria dengan seorang wanita sebagai suami isteri dengan tujuan membentuk keluarga (rumah tangga) yang bahagia dan kekal berdasarkan Ketuhanan Yang Mahaesa" maka tidak dapat terbantahkan dengan keinginan sepihak. Secara komunal, negara menginginkan subjek hukumnya melakukan perkawinan dengan harapan untuk memenuhi negaranya. 
Dengan demikian, kewajiban negara baik pemerintah pusat maupun daerah untuk menyediakan akses perkawinan yang seluas-luasnya kepada seluruh warga negara karena dari perkawinan inilah keluarga dapatlah dibentuk.

Permaslahan hukumnya ketika masyarakat lesbian, gay, biseksual, transeksual (LGBT) sebagai subjek hukum yang selalu berkembang memperoleh perlakuan diskriminatif untuk pemenuhan hak perkawinan(Masthuriyah Sa'dan, 2016). Hal tersebut disebabkan rendahnya kepedulian negara terhadap warga negaranya sehingga walaupun secara tersirat terdapat perlindungan terhadap masyarakat LGBT dalam Undang-Undang Republik Indonesia Nomor 39 Tahun 1999 tentang Hak Asasi Manusia (UU No. 39-1999) dan Prinsip-Prinsip Yogyakarta Tahun 2007 (PPY 2007). Hal lainnya akibat adanya perbedaan orientasi seksual dan identitas gender masyarakat LGBT maka masyarakat LGBT membutuhkan perlindungan dalam pemenuhan hak perkawinan.

Berdasarkan keilmuan hukum, masyarakat LGBT memiliki hak untuk membentuk keluarga melalui perkawinan. Secara normatif dalam Pasal 28A UUD NRI Tahun 1945 bahwa "setiap orang berhak untuk hidup serta berhak mempertahankan hidup dan kehidupannya" dan Pasal 28H ayat (2) UUD NRI Tahun 1945 yang menentukan "Setiap orang berhak mendapat kemudahan dan perlakuan khusus untuk memperoleh kesempatan dan manfaat yang sama guna mencapai persamaan dan keadilan". Lebih lanjut lagi dalam Pasal 10 ayat (1) dan ayat (2) UU No. 39-1999 bahwa "Setiap orang berhak membentuk suatu keluarga dan melanjutkan keturunan melalui perkawinan yang sah" dan "Perkawinan yang sah hanya dapat berlangsung atas kehendak bebas calon suami dan calon istri yang bersangkutan, sesuai dengan ketentuan peraturan perundang-undangan".

Dengan demikian, pemerintah dan pemerintah daerah termasuk Pemerintahan Daerah Provinsi Jawa Timur berkewajiban untuk memenuhi pemenuhan hak perkawinan masyarakat LGBT. Oleh karena itu, penelitian ini akan mengkaji mengenai sejauh mana pemenuhan hak perkawinan bagi masyarakat LGBT di Provinsi Jawa Timur. Untuk mengetahui hal tersebut, maka akan dikaji mengenai norma hukum apa yang telah dan akan diambil oleh Pemerintahan Daerah Provinsi Jawa Timur.

\section{RUMUSAN MASALAH}

Berdasarkan latar belakang di atas, maka terdapat rumusan masalah yang akan dikaji dalam penelitian ini, yaitu bagaimana konsep pengaturan norma hukum tentang pemenuhan hak perkawinan bagi masyarakat LGBT di Provinsi Jawa Timur?

\section{METODE PENELITIAN}

Metode yang digunakan adalah yuridis empiris dengan mengumpulkan dan mengolah data primer yang kemudian dilakukan analisis berdasarkan data sekunder. Data primer diperoleh dan bersumber langsung dari lokasi penelitian yang menjadi sampel dalam penelitian, sedangkan data sekonder diperoleh dari bahan-bahan pustaka (bahan hukum primer dan bahan hukum sekunder). Metode pengumpulan data dengan penelitian kepustakaan dan dokumentasi serta penelitian lapangan melalui wawancara mendalam dan focus group discussion. Analisa dilakukan pada data primer dan sekunder, sehingga penelitian akan menggunakan metode analisis data secara kualitatif empiris.

\section{HASIL}

Perkawinan Menurut Undang-Undang Republik Indonesia Nomor 12 Tahun 2005 Tentang Pengesahan International Covenant On Civil And Political Rights (Kovenan Internasional Tentang Hak-Hak Sipil Dan Politik)

Perkawinan adalah suatu aspek penting di dalam kehidupan manusia dan berlaku umum bagi semua orang. Perkawinan juga berlaku bagi setiap orang sesuai dengan pilihan dan hak tiap-tiap orang 
tersebut. Hak terkait dengan perkawinan juga dapat dilihat pada ketentuan yang ada yaitu UndangUndang Republik Indonesia Nomor 12 Tahun 2005 tentang Pengesahan International Covenant On Civil And Political Rights (Kovenan Internasional tentang Hak-Hak Sipil Dan Politik) yang mana hak asasi harus dijunjung dan dilindungi. Kosideransnya mengatakan hak asasi manusia merupakan hak dasar yang secara kodrati melekat pada diri manusia, bersifat universal dan langgeng, dan oleh karena itu, harus dilindungi, dihormati, dipertahankan, dan tidak boleh diabaikan, dikurangi, atau dirampas oleh siapa pun.

Undang-Undang Republik Indonesia Nomor 12 Tahun 2005 tentang Pengesahan International Covenant On Civil And Political Rights (Kovenan Internasional tentang Hak-Hak Sipil Dan Politik) merupakan suatu hasil dari ratifikasi suatu kovenan yang ada yaitu Kovenan Internasional Hak-Hak Sipil Dan Politik Tahun 16 Desember 1996. Di dalam Kovenan Internasional Hak-Hak Sipil Dan Politik Tahun 16 Desember 1996 ini terdapat suatu pengakuan terhadap hak dari tiap orang yang tertuang pada konsideran yang menentukan bahwa "Mengakui bahwa hak-hak ini berasal dari harkat dan martabat yang melekat pada setiap manusia". Hak-hak tersebut tidak terkecuali dengan hak untuk melaksanakan perkawinan.

Pengakuan terhadap hak tiap manusia ini juga dapat dilihat pada ketentuan Pasal 6 ayat (1) Kovenan Internasional Hak-Hak Sipil Dan Politik Tahun 16 Desember 1996 yang menentukan bahwa "Setiap manusia berhak atas hak untuk hidup yang melekat pada dirinya. Hak ini wajib dilindungi oleh hukum. Tidak seorang pun dapat dirampas hak hidupnya secara sewenang-wenang". Perlindungan terhadap hak tiap orang adalah suatu pelanggaran menurut Kovenan Internasional Hak-Hak Sipil Dan Politik Tahun 16 Desember 1996 ini, salah satunya adalah larangan terhadap seseorang yang ingin menikah dengan seseorang pilihannya.

Hal ini dikarenakan menurut Pasal 23 ayat (2) Kovenan Internasional Hak-Hak Sipil Dan Politik Tahun 16 Desember 1996 menentukan bahwa "Hak laki-laki dan perempuan dalam usia perkawinan untuk menikah dan membentuk keluarga harus diakui." Setiap orang berhak atas pilihannya dalam membangun keluarga yang mereka inginkan menurut Kovenan Internasional Hak-Hak Sipil Dan Politik Tahun 16 Desember 1996. Pasal 23 ayat (1) menentukan bahwa "Keluarga adalah kesatuan kelompok masyarakat yang alamiah serta mendasar dan berhak dilindung oleh masyarakat dan Negara.

Hak untuk membangun sebuah kelaurga yang diidamkan seseorang harus dapat dilindungi dan diakui oleh negara karena hal tersebut adalah hak dari tiap orang yang memiliki hak asasi yang harus dijunjung tinggi oleh orang lain. Terkait hal tersebut dikuatkan dengan ketentuan Pasal 23 ayat (3) dan (4) yang menentukan bahwa:

1. Tidak ada satu pun perkawinan yang dapat dilakukan tanpa persetujuan yang bebas dan penuh dari para pihak yang hendak menikah.

2. Negara Pihak dalam Kovenan ini harus mengambil langkah-langkah yang memadai untuk menjamin persamaan hak dan tanggung jawab pasangan suami istri tentang perkawinan, Dalam halnya berakhirnya perkawinan harus dibuat ketentuan yang diperlukan untuk melindungi anak-anak.

Melihat pada ketentuan di dalam pengaturan Kovenan Internasional Hak-Hak Sipil Dan Politik Tahun 16 Desember 1996 telah jelas bahwa pada dasarnya suatu perkawinan adalah suatu hak yang harus dilindungi dan dihargai oleh orang lain dan negara memiliki peran penting di dalam penegakan hak asasi manusia khususnya di dalam bidang perkawinan.

Perkawinan Menurut UU No.1-1974 Dan Peraturan Pemerintah Republik IndonesiaNomor 9 Tahun 1975 Tentang Pelaksanaan Undang-Undang Nomor 1 Tahun 1974 Tentang Perkawinan

Terdapat suatu asas-asas perkawinan dalam UU No. 1-1974 yaitu: 
1. Tujuan perkawinan adalah membentuk keluarga yang bahagia dan kekal berdasarkan Ketuhanan Yang Maha Esa;

2. Perkawinan merupakan ikatan lahir batin, berdasarkan persatuan kedua belah pihak yang akan melangsungkan perkawinan;

3. Untuk sahnya perkawinan harus di lakukan berdasarkan agama dan kepercayaan yang akan melangsungkan perkawinan;

4. Peristiwa perkawinan harus di lakukan pencatatan berdasarkan peraturan yang ada;

5. Kedudukan suami istri adalah seimbang dalam rumah tangga dan pergaulan hidup bersama dalam masyarakat, masing-masing pihak berhak melakukan perbuatan hukum;

6. Berdasarkan alasan serta syarat-syarat tertentu juga izin pengadilan seorang pria boleh beristri lebih dari satu asas monogami;

7. Untuk dapat melangsungkan perkawinan ditentukan batas umur serendah-rendahnya bagi pria 19 (sembilan belas) tahun dan bagi wanita 16 (enam belas) tahun dan izin orang tua masih diperlukan sampai yang akan melangsungkan perkawinan mencapai usia 21 (dua puluh satu) tahun.

Melihat pada tujuan perkawinan di atas, maka terdapat suatu syarat yang harus dipenuhi untuk dapat melangsungkan perkawinan. Syarat-syarat ini terdapat di dalam Pasal 6 UU No. 1-1974 yang menentukan bahwa:

1) Perkawinan didasarkan atas persetujuan kedua calon mempelai.

2) Untuk melangsungkan perkawinan seorang yang belum mencapai umur 21 (dua puluh satu) tahun harus mendapat izin kedua orang tua.

3) Dalam hal seorang dari kedua orang tua meninggal dunia atau dalam keadaan tidak mampu menyatakan kehendaknya, maka izin yang dimaksud ayat (2) Pasal ini cukup diperoleh dari orang tua yang masih hidup atau dari orang tua yang mampu menyatakan kehendaknya.

4) dalam hal kedua orang tua telah meninggal dunia atau dalam keadaan tidak mampu untuk menyatakan kehendaknya, maka izin diperoleh dari wali orang yang memelihara atau keluarga yang mempunyai hubungan darah dalam garis keturunan lurus ke atas selama mereka masih hidup dan dalam keadaan menyatakan kehendaknya.

5) Dalam hal ada perbedaan antara orang-orang yang dimaksud dalam ayat (2), (3) dan (4) Pasal ini, atau salah seorang atau lebih diantara mereka tidak menyatakan pendapatnya, maka Pengadilan dalam daerah tempat tinggal orang yang akan melangsungkan perkawinan atas permintaan orang tersebut dapat memberikan ijin setelah lebih dahulu mendengar orang-orang yang tersebut dalam ayat (2), (3) dan (4) dalam Pasal ini.

6) Ketentuan tersebut ayat (1) sampai dengan ayat (5) Pasal ini berlaku sepanjang hukun masingmasing agamanya dan kepercayaannya itu dari yang bersangkutan tidak menentukan lain.

Melihat pada tujuan yang dijelaskan pada UU No. 1-1974 di atas, maka terdapat suatu unsur utama yaitu adanya kesepakatan yang diperoleh dari kedua belah pihak yang melangsungkan perkawinan tersebut. Hal ini dikarenakan perkawinan pada dasarnya tidak bisa dilangsungkan atas dasar paksaan dari satu pihak, karena menurut Pasal 8 UU No. 1-1974 terdapat suatu larangan-larangan yang harus dihindari, yaitu:

a. berhubungan darah dalan garis keturunan lurus ke bawah atau ke atas;

b. berhubungan darah dalam garis keturunan menyamping yaitu antara saudara, antara seorang dengan seorang saudara orang tua dan antara seorang dengan saudara neneknya;

c. berhubungan semenda, yaitu mertua, anak tiri, menantu dan ibu/bapak tiri;

d. berhubungan susuan, anak susuan, saudara dan bibi/paman susuan;

e. berhubungan saudara dengan isteri atau sebagai bibi atau kemenakan dari isteri, dalam hal seorang suami beristeri lebih dari seorang; 
f. yang mempunyai hubungan yang oleh agamanya atau praturan lain yang berlaku dilarang kawin.

Terkait dengan larangan-larangan tersebut, maka perkawinan dapat dicegah apabila ada orang yang tidak memenuhi syarat-syarat untuk melangsungkan perkawinan. Pihak pencegah adalah para keluarga dalam gari keturunan lurus ke atas dan ke bawah, saudara, wali nikah, wali pengampu dari salah seorang calon mempelai dan pihak-pihak yang berkepentingan. Dengan adanya pencegahan yang dilakukan maka apabila telah terjadi perkawinan yang tidak memenuhi syarat, maka perkawinan tersebut dapat dibatalkan. Selain itu, terdapat juga pasal yang memperbolehkan seseorang untuk membatalkan suatu perkawinan, hal ini dapat dilihat pada ketentuan Pasal 26 UU No. 1-1974 yang menentukan bahwa:

Perkawinan yang dilangsungkan dimuka pegawai pencatat perkawinan yang tidak berwenang, wali nikah yang tidak sah atau yang dilangsungkan tanpa dihadiri oleh 2 (dua) orang saksi dapat dimintakan pembatalannya oleh keluarga dalam garis keturunan lurus ke atas dari suami atau isteri, jaksa dan suami atau isteri.

Selain berdasarkan pengaturan peraturan perundang-undangan di atas, pembatalan perkawinan juga diutarakan oleh para ahli. Dalam hal ini menurut Riduan Syahrani terkait dengan pembatalan perkawinan yaitu seperti yang mengatakan bahwa "Suatu perkawinan dapat dibatalkan apabila perkawinan itu dilangsungkan oleh para pihak (suami istri) atau salah satu pihak (suami-istri) terbukti tidak memenuhi syarat-syarat untuk berlangsungnya perkawinan"(Syahrani and Abdurrahman, 1086). Sama halnya dengan pencegahan perkawinan, maka pembatalan perkawinan juga dapat dilakukan oleh beberapa pihak yang dalam hal ini diatur di dalam Pasal 23 UU No. 1-1974 yaitu:

a. Para keluarga dalam garis keturunan lurus ke atas dari suami atau isteri.

b. Suami atau isteri.

c. Pejabat yang berwenang hanya selama perkawinan belum diputuskan.

d. Pejabat yang ditunjuk tersebut ayat (2) Pasal 16 Undang-undang ini dan setiap orang mempunyai kepentingan hukum secara langsung terhadap perkawinan tersebut, tetapi hanya setelah perkawinan itu putus.

Selanjutnya menurut K.Wantjik Saleh mengutarakan siapa saja yang dapat melakukan pembatalan perkawinan yaitu sebagai berikut:

a. Para keluarga dalam garis keturunan ke atas dari suami atau isteri

b. Suami atau isteri

c. Pejabat yang berwenang

d. Pejabat yang ditunjuk

e. Jaksa.(Saleh, 1980)

Beberapa pihak tersebut pada selanjutnya dapat melakukan usaha pembatalan perkawinan melalui pengadilan negeri, dimana hal ini diatur di dalam Pasal 25 UU No. 1-1974 yang menentukan bahwa "Permohonan pembatalan perkawinan diajukan kepada Pengadilan dalam daerah hukum dimana perkawinan dilangsungkan ditempat tinggal kedua suami isteri, suami atau isteri".

Selain berdasarkan UU No. 1-1974 tersebut, terdapat pula suatu peraturan perundang-undangan yang menjadi peraturan pelaksana dari UU No. 1-1974 yaitu Peraturan Pemerintah Republik Indonesia Nomor 9 Tahun 1975 tentang Pelaksanaan Undang-Undang Nomor 1 Tahun 1974 tentang Perkawinan. Di dalam Peraturan Pemerintah Republik IndonesiaNomor 9 Tahun 1975 tentang Pelaksanaan UndangUndang Nomor 1 Tahun 1974 tentang Perkawinan ini banyak sekali mengatur tentang tata cara yang bersifat prosedural bagi seseorang yang ingin melakukan perkawinan.

Cara dan prosedural ini dapat dilihat dimulai dari suatu pemberitahuan perkawinan hingga sampai selesainya prosedur perkawinan itu sendiri. Prosedural tersebut dimulai dengan suatu kehendak atau pemberitahuan kepada pihak yang terkait, hal ini seperti yang tertera di dalam Pasal 3 Peraturan 
Pemerintah Republik IndonesiaNomor 9 Tahun 1975 tentang Pelaksanaan Undang-Undang Nomor 1 Tahun 1974 tentang Perkawinan yang menentukan bahwa:

1) Setiap orang yang akan melangsungkan perkawinan memberitahukan kehendaknya itu kepada Pegawai Pencatat ditempat perkawinan akan dilangsungkan.

2) Pemberitahuan tersebut dalam ayat (1) dilakukan sekurang-kurangnya 10 (sepuluh) hari kerja sebelum perkawinan dilangsungkan.

3) Pengecualian terhadap jangka waktu tersebut dalam ayat (2) disebabkan sesuatu alasan yang penting, diberikan oleh Camat atas nama Bupati Kepala Daerah.

Selain berdasarkan Pasal 3 di atas, di dalam Pasal 4 Peraturan Pemerintah Republik IndonesiaNomor 9 Tahun 1975 tentang Pelaksanaan Undang-Undang Nomor 1 Tahun 1974 tentang Perkawinan juga menentukan bahwa cara melakukan pemberitahuan yaitu sebagai berikut "Pemberitahuan dilakukan secara lisan atau tertulis oleh calon mempelai, atauoleh orang tua atau wakilnya".

Setelah calon mempelai melakukan pemberitahuan, menurut Pasal 10 Peraturan Pemerintah Republik Indonesia Nomor 9 Tahun 1975 tentang Pelaksanaan Undang-Undang Nomor 1 Tahun 1974 tentang Perkawinan menentukan prosedur selanjutnya yaitu:

1) Perkawinan dilangsungkan setelah hari kesepuluh sejak pengumumankehendak perkawinan oleh Pegawai Pencatat seperti yang dimaksud dalam Pasal 8 Peraturan Pemerintah ini.

2) Tatacara perkawinan dilakukan menurut hukum masing-masing agamanya dan kepercayaannya itu.

3) Dengan mengindahkan tata cara perkawinan menurut masing-masing hukum agamanya dan kepercayaannya itu, perkawinan dilaksanakan dihadapan Pegawai Pencatat dan dihadiri oleh dua orang saksi.

Prosedur selanjutnya yang harus dilalui para calon mempelai adalah dengan merujuk kepada Pasal 2 Peraturan Pemerintah Republik IndonesiaNomor 9 Tahun 1975 tentang Pelaksanaan Undang-Undang Nomor 1 Tahun 1974 tentang Perkawinan yang menentukan bahwa:

1) Pencatatan perkawinan dari mereka yang melangsungkan perkawinannya menurut agama Islam, dilakukan oleh Pegawai Pencatat sebagaimana dimaksud dalam Undang-undang Nomor 32 Tahun 1954 tentang Pencatatan Nikah, Talak dan Rujuk.

2) Pencatatan perkawinan dari mereka yang melangsungkan perkawinannya menurut agamanya dan kepercayaannya itu selain agama Islam, dilakukan oleh Pegawai Pencatat perkawinan pada kantor catatan sipil sebagaimana dimaksud dalam berbagai perundang-undangan mengenai pencatatan perkawinan.

3) Dengan tidak mengurangi ketentuan-ketentuan yang khusus berlaku bagi tatacara pencatatan perkawinan berdasarkan berbagai peraturan yangberlaku, tatacara pencatatan perkawinan dilakukan sebagaimana ditentukan dalam Pasal 3 sampai dengan Pasal 9 Peraturan Pemerintah ini.

Pemberitahuan dan pencatatan perkawinan tersebut merupakan suatu beberapa cara atau prosedural yang harus dilalui para calon mempelai. Selanjutnya terdapat satu hal yang juga diatur di dalam UU No. 1-1974 yaitu yang terkait dengan pembatalan perkawinan. Aturan tentang pembatalan perkawinan juga diatur di dalam Peraturan Pemerintah Republik Indonesia Nomor 9 Tahun 1975 tentang Pelaksanaan Undang-Undang Nomor 1 Tahun 1974 tentang Perkawinan yaitu Pasal 37 yang menentukan bahwa "Batalnya suatu perkawinan hanya dapat diputuskan oleh Pengadilan". Pembatalan ini dapat diajukan oleh pihak pihak yang berhak sesuai dengan ketentuan UU No. 1-1974. Melalui Pasal 38 Peraturan Pemerintah Republik Indonesia Nomor 9 Tahun 1975 tentang Pelaksanaan Undang-Undang Nomor 1 Tahun 1974 tentang Perkawinan, pembatalan tersebut dilakukan dengan cara:

1) Permohonan pembatalan suatu perkawinan diajukan oleh pihak-pihak yang berhak mengajukannya kepada Pengadilan yang daerah hukumnya meliputi tempat berlangsungnya perkawinan, atau di tempat tinggal kedua suami-isteri, suami atau isteri. 
2) Tatacara pengajuan permohonan pembatalan perkawinan dilakukan sesuai dengan tatacara pengajuan gugatan perceraian.

3) Hal-hal yang berhubungan dengan pemeriksaan pembatalan perkawinandan putusan Pengadilan, dilakukan sesuai dengan tatacara tersebut dalam Pasal 20 sampai dengan Pasal 36 Peraturan Pemerintah ini.

Setelah mengetahui aturan dan prosedural dari suatu perkawinan, selanjutnya melalui perkawinan itu sendiri memiliki hak-hak yang dilindungi oleh undang-undang.

\section{Perkawinan Menurut UU No. 39-1999}

Sama halnya dengan UU No. 1-1974, maka UU No. 39-1999 juga mengatur walaupun tidak spesifik tentang perkawinan seseorang. Perkawinan menurut UU No. 39-1999 merupakan suatu hak dasar yang dimiliki oleh setiap orang hal ini dapat dilihat pada ketentuan Pasal 10 Undang-Undang Republik Indonesia Nomor 39 Tahun 1999 tentang Hak Asasi Manusia yang menentukan bahwa "Setiap orang berhak membentuk sebuah keluarga dan melanjutkanketurunan melalui perkawinan yang sah".

Dengan adanya Pasal 10 di atas, maka secara tidak langsung UU No. 39-1999 telah memberikan hak bagi tiap orang untuk melakukan perkawinan sebelum perkawinan itu dilakukan. Akan tetapi tidak hanya memiliki hak untuk melakukan perkawinan, tiap pihak juga harus melihat pada ketentuan ayat (2) Pasal 10 yang menentukan bahwa "Perkawinan yang sah hanya dapat berlangsung atas dasar kehendak bebas calon suami dan calon istriyang bersangkutan, sesuaidengan ketentuan peraturanperundangundangan".

Sesudah mengetahui hak dari seseorang sebelum adanya perkawinan, maka selanjutnya tiap orang tersebut juga memiliki hak yang harus dijunjung tinggi oleh pihak lain setelah adanya ikatan perkawinan tersebut. Hal ini dapat dilihat pada Pasal 51 UU No. 39-1999 yang menentukan bahwa:

Seorang istri selama dalam ikatan perkawinan mempunyai hak dan tanggung jawab yang sama dengansuaminya atas semua hal yang berkenaan dengan perkawinannya, hubungan dengan anak-anaknya,dan hak pemilikan dan pengolahan harta bersama.

\section{Perkawinan Menurut PPY 2007}

Selain berdasarkan banyaknya pengaturan tentang perkawinan menurut peraturan perundangundangan dan instrumen hukum lainnya, terdapat pula suatu pengaturan terkait perkawinan yang khusus mengatur tentang LGBT dalam hal penegakkan hak tiap tiap LGBT dalam segala hal salah satunya adalah perkawinan. Menurut PPY 2007 terdapat banyak sekali pengaturan hak-hak tiap orang yang diatur, hak-hak tersebut adalah sebagai berikut:

1. Hak Atas Nikmat Karunia Hak-Hak Asasi Manusia Universal;

2. Hak-Hak Atas Kesetaraan Dan Non-Diskriminasi;

3. Hak Atas Pengakuan Hukum;

4. Hak Atas Kehidupan;

5. Hak Atas Rasa Aman;

6. Hak Atas Ruang Privat (Privasi);

7. Hak Atas Kemerdekaan Dari Pencabutan Kebebasan Secara Sewenang-wenang;

8. Hak Atas Pemeriksaan Pengadilan Secara Adil;

9. Hak Atas Perlakuan Manusiawi Selama Dalam Tahanan;

10. Hak Atas Kebebasan dari Penyiksaan dan Perlakuan Atau Hukuman yang Kejam, Tidak Manusiawi Atau Merendahkan Martabat;

11. Hak Atas Perlindungan Dari Semua Bentuk Eksploitasi, Jual-Beli Dan Perdagangan Manusia;

12. Hak Atas Pekerjaan; 
13. Hak Atas Jaminan Sosial Dan Tindakan Perlindungan Sosial Lainnya;

14. Hak Atas Standard Hidup Yang Layak;

15. Hak Atas Pemukiman Yang Layak;

16. Hak Atas Pendidikan;

17. Hak Atas Standard Kesehatan Tertinggi Yang Dapat Dicapai Perlindungan Dari Penyalah-Gunaan Medis;

18. Hak Atas Kemerdekaan Berpendapat Dan Berekspresi;

19. Hak Atas Kemerdekaan Berkumpul Dan Berorganisasi Dengan Damai;

20. Hak Atas Kemerdekaan Pikiran, Hati Nurani Dan Agama;

21. Hak Atas Kemerdekaan Berpindah-Tempat;

22. Hak Untuk Mencari Tempat Perlindungan (Suaka);

23. Hak Untuk Membangun Keluarga;

24. Hak Untuk Berperan-Serta Dalam Kehidupan Bermasyarakat;

25. Hak Untuk Berperan-Serta Dalam Berkebudayaan;

26. Hak Untuk Memperjuangkan Hak Asasi Manusia;

27. Hak Untuk Memperoleh Pengobatan Dan Penggantian Kerugian Yang Efektif.

Salah satu aspek yang ada di dalam pengaturan PPY 2007 adalah hak yang terkait dengan hak untuk membagun keluarga. Hak untuk membangun keluarga disini adalah kaitannya dengan hak asasi manusia yang berhak memilih siapa sajayang akan menjadi pasangannya.

Di dalam kata pengantar alinea pertama PPY 2007 tersebut telah jelas diterangkan bahwa:

Semua manusia terlahir merdeka dan sejajar dalam martabat dan hak-haknya. Semua manusia memiliki sifat universal, saling bergantung, tak dapat dibagi dan saling berhubungan. Orientasi seksualdan identitas genderbersifat menyatu dengan martabat dan kemanusiaan setiap orang serta tak boleh menjadi dasar bagi adanya diskriminasi ataupun kekerasan.

Selain berdasarkan kata pengantar tersebut, terdapat pula pengaturan tentang betapa pentingnya hak asasi manusia pada setiap orang, hal ini dapat dilihat pada mukadimah alinea pertama PPY 2007 yang menentukan bahwa:

MENGINGAT bahwa semua manusia dilahirkan merdeka dan setara dalam martabat dan hak asasi, dan bahwa setiap orang berhak atas nikmat karunia hak-hak asasi manusia tanpa perbedaan apapun seperti ras, warna kulit, jenis kelamin, bahasa, pendapat politik ataupun pendapat lain, asal kebangsaan maupun strata sosial, hak milik, status kelahiran ataupun status lain;

Hak asasi manusia yang tertuang di dalam kata pengantar dan mukadimah tersebut, salah satu bentuk hak asasi manusia yang harus dijunjung tinggi adalah hal perkawinan yang tidak memandang jenis kelamin yang diatur di dalam Pasal 24 PPY 2007:

Setiap orang berhak untuk membangun keluarga, tanpa memandang orientasi seksual atau identitas gendernya. Keluarga ada dalam berbagai bentuk. Tak satu pun keluarga boleh menjadi sasaran diskriminasi berdasarkan orientasi seksual atau identitas gender dari anggotaanggotanya.

Dengan segala bentuk dari kata pengantar dan mukadimah PPY 2007 tersebut, maka dapat dilihat secara sekilas bahwa hak asasi manusia harus dapat dijunnjung tinggi oleh setiap orang salah satunya adalah terkait hal perkawinan sejenis. Hal ini dikarenakan hak asasi manusia terkait perkawinan sejenis menurut PPY 2007:

Setiap orang secara individual maupun bersama-sama dengan orang lain berhak untuk memperjuangkan perlindungan dan perwujudan hak asasi manusia di tingkat nasional dan internasional, tanpa diskriminasi berdasarkan orientasi seksual atau identitas gender. Ini 
mencakup kegiatan-kegiatan yang ditujukan ke arah perjuangan dan perlindungan terhadap hakhak orang-orang yang memiliki orientasi seksual dan identitas gender berbeda, sebagaimana hak untuk mengembangkan dan membahas norma-norma baru hak asasi manusia serta untuk memberikan advokasi terhadap penerimaan mereka.

Dengan orientasi terhadap seksual seperti yang diatur dalam Pasal 25 PPY 2007 maka setiap perkawinan sejenis harus dan dapat dipertahankan.

\section{Wawancara Dengan Organisasi LGBT Dan Agama}

Untuk mendukung penelitian maka wawancara telah dilakukan pada rentang bulan April hingga Juni 2018. Wawancara ini dilakukan secara mendalam dimana dalam wawancara terdapat hasil yaitu:

a. Organisasi LGBT menginginkan suatu pengakuan dimana pengakuan adalah kesadaran masyarakat agar tidak melakukan persekusi dalam hal apapun. Penerimaan terhadap organisasi LGBT adalah kemutlakan karena kesadaran mereka terhadap tujuan akhir perkawinan di Indonesia adalah hal tidak dapat terjadi.

b. Organisasi agama mengatakan bahwa dalam ajaran agama apapun menolak secara tegas terkait perkawinan sejenis LGBT namun menolak ketegasan pemerintah dalam memidana mereka. ketika negara bertindak tegas maka ketegasan itu tidak serta merta disamaratakan dengan subjek hukum lainnya. Negara harus memiliki peduli dengan memberikan kesempatan hak untuk bekerja, perlindungan hukum ataupun ekspresi diri.

\section{PENUTUP}

Nawacita merupakan kesatuan yang tidak dapat dipisahkan dengan PPY 2007. Ketika PPY 2007 dianggap sebagai suatu penyesatan maka perubahan paradigma menuju pemikiran mendatang adalah sebuah kemutlakan. Selain itu, nawacita adalah wujud terbaik untuk memahami PPY 2007. Jadi nawacita merupakan salah satu cara mengatasi PPY 2007. PPY 2007 sebagai norma yang tidak tertulis walaupun ia tertulis tapi tidak terlegalkan.

\section{DAFTAR PUSTAKA}

Masthuriyah Sa'dan (2016) 'LGBT Dalam Perspektif Agama dan HAM', Jurnal NIZHAM, 5(1). Saleh, K. W. (1980) Hukum Perkawinan Indonesia, . Jakarta: Ghalia Indonesia.

Syahrani, R. and Abdurrahman (1086) Masalah-Masalah Hukum Perkawinan Di Indonesia,. Jakarta: Media Sarana Press.

\section{UCAPAN TERIMA KASIH}

Peneliti mengucapkan terima kasih kepada

c. Direktorat Riset dan Pengabdian Masyarakat Direktorat Jenderal Penguatan Riset dan Pengembangan Kementerian Riset, Teknologi, dan Pendidikan Tinggi Tahun 2017-2018.

d. Dr. Ir. Muslimin Abdulrahim, M.Sc., sebagai Ketua Lembaga Penelitian dan Pengabdian Kepada Masyarakat Universitas 17 Agustus 1945 Surabaya.

e. Dr. Slamet Suhartono, S.H., M.H., sebagai Dekan Fakultas Hukum Universitas 17 Agustus 1945 Surabaya.

f. Prof. Dr. Made Warka, S.H., M.Hum., sebagai Wakil Dekan Fakultas Hukum Universitas 17 Agustus 1945 Surabaya. 
Prosiding SEMATEKSOS 3"Strategi Pembangunan Nasional Menghadapi Revolusi Industri 4.0"

g. Narasumber yang telah memberikan waktu luangnya sehingga penelitian ini dapat dipertanggungjawabkan secara ilmiah. 